\title{
Factors related to adherence to antiretroviral treatment in a specialized care facility
}

\author{
Kamila Tessarolo Velame ${ }^{1}$ \\ (iD) Renata de Souza da Silva² \\ (iD) Crispim Cerutti Junior ${ }^{3}$
}

\begin{abstract}
1. Universidade de São Paulo, São Paulo, SP, Brasil 2. Universidade Federal do Espírito Santo, Vitória, ES, Brasil 3. Departamento de Medicina Social. Universidade Federal do Espírito Santo, Vitória, ES, Brasil
\end{abstract}

http://dx.doi.org/10.1590/1806-9282.66.3.290

\begin{abstract}
SUMMARY
The objective of this study was to verify the level of adherence to antiretroviral treatment and its associated factors. This is a descriptive cross-sectional study based on data retrieved from medical records. To achieve this, we used a questionnaire composed of sociodemographic and clinical information recorded from patients aged between thirteen and fifty-nine years who attended a specialized service from 2007 to 2014. The chi-square test was performed to verify the association of the outcome with the categorical variables. Continuous variables were compared through the Student t-test. Thirteen variables were analyzed in the bivariate model, resulting in the selection of the following variables to the multivariate model $(p<0.20)$ age of discovery $(p=0.12)$, age $(p=0.14)$, skin color $(p=0.12)$, level of education $(p=0.03)$, time since HIV diagnosis $(p<0.001)$ and AIDS case $(p<0.001)$. Among the six variables selected for the multivariate model, cases of aids $(p<0.001)$ remained significant. We concluded that having aids decreases the probability of non-adherence to antiretroviral treatment by $92 \%$. These results indicate that symptomatic patients have better adherence to therapy.
\end{abstract}

KEYWORDS: HIV. Acquired immunodeficiency syndrome. Anti-retroviral agents. Medication adherence. Therapeutics. Health services.

\section{INTRODUCTION}

Antiretroviral therapy (ART) emerged in the 1990s, resulting in an increase in survival rates. Nowadays, the term 'survival' is no longer used because ART has eliminated the prospect of short-term death, ensuring a life expectancy similar to that of non-infected individuals, provided there is proper adherence to therapy'.

Brasil has been a pioneer in adopting a public policy of universal free access to antiretroviral treatment, even at an international level. In 1996, Brasil implemented high-efficacy antiretroviral therapy, whose greatest success was adopting a regime of three antiretroviral medications (triple therapy)2. The universal access to these drugs in Brasil resulted in a change in the characteristic of acquired immunodeficiency syndrome (AIDS), from a disease of high lethality to a controllable chronic disease ${ }^{3}$.

The quality of life provided by the universal access to therapy is evidenced by statistical data reproduced by the Global Report of the Joint United Nations Program on Human Immunodeficiency Virus (HIV)/ AIDS (UNAIDS) ${ }^{4}$, which proved a significant decline in mortality due to aids, not only in Brasil but in all 
other countries. In 2013, there was a reduction of 800,000 deaths ${ }^{5}$.

In 2015, UNAIDS established ambitious goals for HIV through a protocol that aims to chart new directions for the treatment of the virus. The goals for 2020 include the knowledge of their seropositive status by $90 \%$ of all people living with HIV, uninterrupted antiretroviral therapy for $90 \%$ of all people diagnosed with HIV infection, and viral suppression in $90 \%$ of all people receiving antiretroviral therapy ${ }^{4}$.

Currently, in Brasil, it is estimated that $83 \%$ of those infected know their diagnosis, $62 \%$ are undergoing medical treatment, and $88 \%$ have an undetectable viral load. Thus, in order to achieve the goal established by UNAIDS, it is necessary that those affected by the disease have continued medical monitoring.

Considering the above, the objective of this study was to determine the levels of adherence to antiretroviral treatment and the factors related to it by evaluating patients with HIV/Aids in the aged between 13 and 59 years old and treated in a Specialized Care Service (SAE), located in the municipality of Vitória, Espírito Santo (ES), between 2007 and 2014.

\section{METHODS}

This is a descriptive, cross-sectional study based on a quantitative approach to identify and assess patients from 13 to 59 years old treated in the Center of Reference for Sexually Transmitted Diseases (STD/AIDS), located in the municipality of Vitória, ES, between 2007 and 2014.

All information was obtained by using a structured form for data collection. The form was divided into two stages, one containing questions related to sociodemographic aspects and the other to the clinical aspects.

We considered a minimum frequency of poor adherence of $5 \%$ for any of the categories present among the participants. To obtain a population estimate, considering a confidence interval of 95\%, a sample of 102 individuals would be required to discriminate a five-times-higher frequency of poor adherence in a risk category, with $80 \%$ of power. Since there were 20 adolescents aged between 13 and 19 years old recorded in the SAE, we decided to include all of them plus a sample of 100 adults, which, in a direct comparison of age ranges, resulted in a ratio of 1:5.

Data were collected from patients' medical records, and we selected those aged from 13 to 59 years. We randomly drew 100 records from the 849 of patients aged between 19 and 59 years, since all adolescents aged between 13 and 19 years were included. The collection period lasted from November 2015 to March 2016.

Regarding the treatment adherence criterion, we classified as adherent members who continued ART without interruptions from the time of diagnosis until the day of data collection, i.e., the criterion used was medication pick-up from the SAE pharmacy. Those who abandoned therapy for any period or permanently were classified as non-adherent.

The categorical variables were represented by their absolute and relative frequencies. The continuous quantitative variables were represented by their central position and variability. Since all fit the Gauss model, we used mean and standard deviation. The bivariate analysis considered a dichotomous outcome (adherence or not), assessing its possible association with several variables. The association of the outcome with the categorical variables was verified by the Chisquare test, except when expected frequencies found were lower than five, in which case the maximum likelihood ratio (more than two categories) was used. Continuous variables were compared by Student's t-test (two groups). To measure the effect, we used the odds ratio with their respective confidence intervals of $95 \%$.

Variables with a p-value of less than 0.2 in the bivariate analysis were included in the multivariate model, which comprised binomial logistic regression. The data were analyzed using Statistical Package for Social Sciences (SPSS), version 17.0, and presented in simple frequency tables.

This study was preceded by the approval of the Research Ethics Committee of the Federal University of Espírito Santo (UFES) (CAAE No. 46032915.9.0000.5060).

\section{RESULTS}

Of the 120 forms filled out, 79 (65.8\%) belonged to male individuals, and their average age until the day of the collection was 36.3 years. There were 41 females (34.2\% of the collected data), with an average age of 38.2 years. The distribution according to skin color revealed that $77(64.2 \%)$ were brown, 22 (18.3\%) were white, and 21 (17.5\%) were black. Regarding formal education aspects, considering valid records, 27 (27.3\%) had not completed primary education, and 24 (24.2\%) had completed secondary education (Figure 1). With respect to occupations, we decided to categorize 
patients between those who exercise (87 - 76.3\%) or not (27 - 23.7\%) a profession and then into jobs that require secondary education, corresponding to 66 individuals (57.9\%), those that require an university degree, with a total of 21 individuals $(18.4 \%)$, and those that do not apply, which included 27 individuals (23.7\%) who were students, unemployed, or homemakers.

Regarding the distribution of people living with HIV/aids, according to the clinical variables, we found that the main source of infection by the virus was through sex, corresponding to 111 people (97.4\%). We observed that the time for the diagnosis of HIV was an average of 63.6 months and 77 individuals (67\%) progressed to AIDS. The Viral Load (VL) was undetectable in 67 patients (75.3\%). The CD4 lymphocyte count had an average of 608.53 cells $/ \mathrm{mm} 3$. Regarding a previous history of opportunistic infections, we observed that $66.7 \%$ had no history, as shown in Table 1.

Initially, we searched for an association between the adherence or non-adherence and sociodemographic and clinical variables. There was a significant difference $(p<0.05)$ concerning the age at the time of diagnosis. Regarding skin color, brown-skinned people showed better adherence when compared to blacks and whites.
In relation to formal education, people with higher educational levels showed greater adherence, with statistical significance. As to the clinical variables, we found a significant difference in adherence among those with an AIDS diagnosis $(p<0.001)$ (Figure 1). There was significance regarding viral load $(\mathrm{p}=0.04)$; however, it was not included in the multivariate model because its increased level is a natural consequence of non-adherence and could act as a confounding variable. The prevalence of non-adherence was $43.3 \%$ in the sample.

Among the 13 variables analyzed, six were included in the logistic regression model. The results of the analysis (Table 2) showed that an aids diagnosis is associated with better adherence to antiretroviral treatment.

\section{DISCUSSION}

In the present study, we observed that an aids diagnosis improves adherence to antiretroviral therapy. Other variables that are considered as potential risk factors for non-adherence, such as education and marital status, showed no significant association with the outcome of interest (adherence).

FIGURE 1. CATEGORICAL VARIABLES INCLUDED IN THE LOGISTIC REGRESSION MODEL
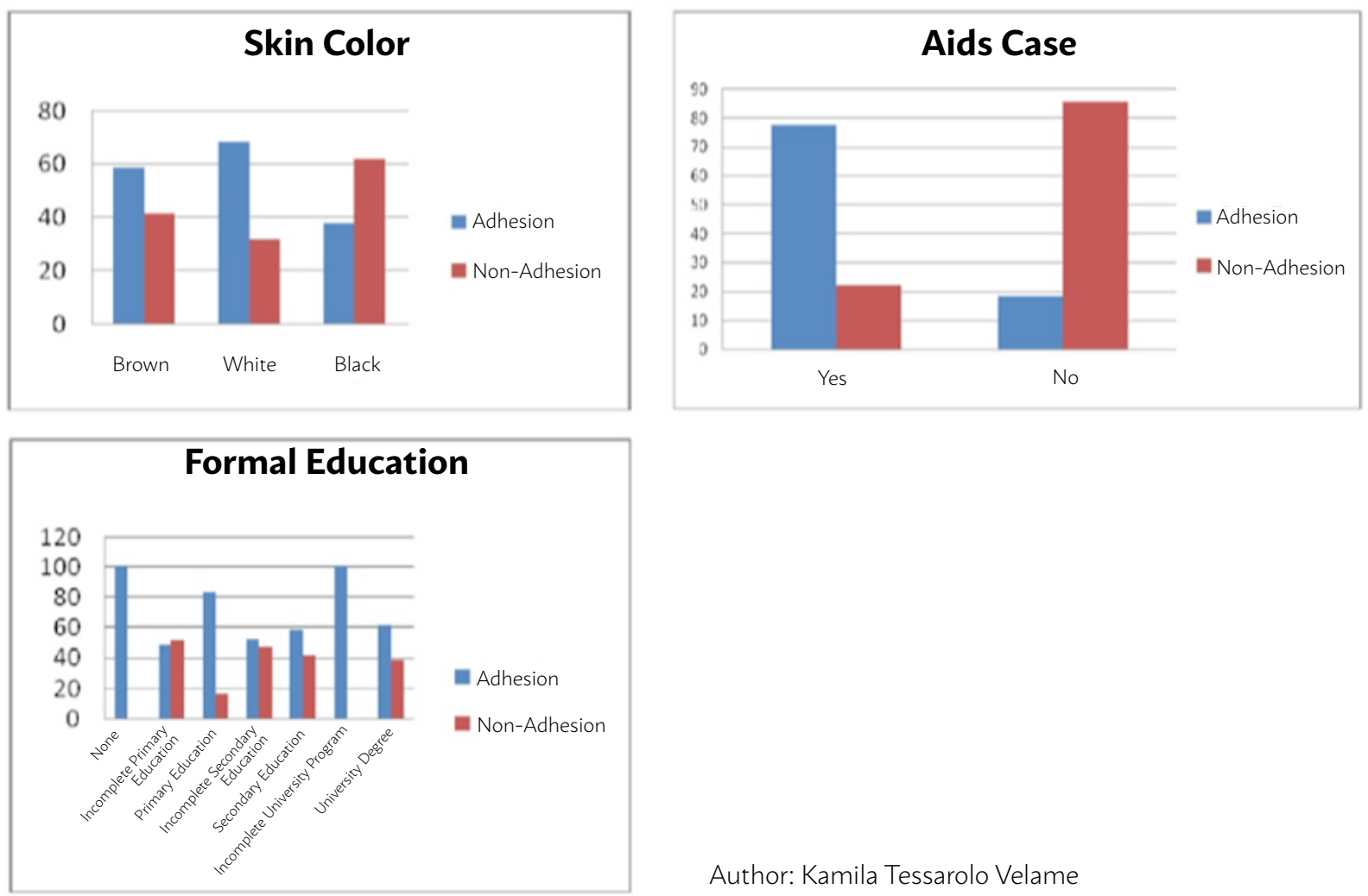

Author: Kamila Tessarolo Velame 
TABLE 1. CLINICAL AND SOCIODEMOGRAPHIC CHARACTERISTICS OF A SAMPLE OF 120 INDIVIDUALS AGED BETWEEN 13 AND 59 YEARS IN FOLLOW-UP IN THE CENTER OF REFERENCE FOR STD/AIDS* OF VITÓRIA, ES, BRASIL, 2007 TO 2014.

\begin{tabular}{|c|c|c|c|c|c|}
\hline \multicolumn{2}{|l|}{ Variables } & \multirow{2}{*}{$\begin{array}{l}\text { Adherence } \\
\text { n (\%) } \\
22(53.2) \\
\end{array}$} & \multirow{2}{*}{\begin{tabular}{|l}
$\begin{array}{l}\text { Non-adherence } \\
\mathrm{n}(\%)\end{array}$ \\
$19(46.3)$ \\
\end{tabular}} & \multirow{2}{*}{\begin{tabular}{|l|} 
Total \\
n (\%)
\end{tabular}} & \multirow{2}{*}{$\begin{array}{l}\text { P-value } ¥ \\
\text { 0.63a }\end{array}$} \\
\hline Gender & Female & & & & \\
\hline & Male & $46(58.2)$ & $33(41.8)$ & $79(65.8)$ & \\
\hline \multicolumn{2}{|c|}{ Age (years) mean (SD) } & $38.2(11.7)$ & $35.3(9.3)$ & & $0.14 b$ \\
\hline \multicolumn{2}{|c|}{ Age of diagnosis (years) average (SD) } & $34.2(11.1)$ & $29.4(9.1)$ & & $0.12 b$ \\
\hline \multirow{3}{*}{ Skin color } & Brown & $45(58.4)$ & $32(41.6)$ & $77(64.2)$ & \\
\hline & White & $15(68.2)$ & $7(31.8)$ & $22(18.3)$ & $0.12 a$ \\
\hline & Black & $8(38.1)$ & $13(61.9)$ & $21(17.5)$ & \\
\hline \multirow[t]{5}{*}{ Marital status } & Single & $51(63.0)$ & $30(37.0)$ & $81(67.5)$ & \\
\hline & Married & $11(45.8)$ & $13(54.2)$ & $24(20.0)$ & \\
\hline & Divorced/separated & $5(55.6)$ & $4(44.4)$ & $9(7.5)$ & $0.4 a$ \\
\hline & Widow(er) & $1(50.0)$ & $1(50.0)$ & $2(1.7)$ & \\
\hline & Stable union & $0(0.0)$ & $1(100.0)$ & $1(0.8)$ & \\
\hline \multirow[t]{7}{*}{ Formal education } & None & $3(100.0)$ & $0(0.0)$ & $3(3.0)$ & \\
\hline & Incomplete primary education & $13(48.1)$ & $14(51.9)$ & $27(27.3)$ & \\
\hline & Primary education & $5(83.3)$ & $1(16.7)$ & $6(6.1)$ & \\
\hline & Incomplete secondary education & $10(52.6)$ & $9(47.4)$ & 19(19.2) & $0.03 a$ \\
\hline & Secondary education & $14(58.3)$ & $10(41.7)$ & $24(24.2)$ & \\
\hline & Incomplete university program & $7(100.0)$ & $0(0.0)$ & $7(7.1)$ & \\
\hline & University degree & $8(61.5)$ & $5(38.5)$ & $13(13.1)$ & \\
\hline \multirow[t]{2}{*}{ Occupation $1 \S$} & Yes & $51(58.6)$ & $36(41.4)$ & $87(76.3)$ & \multirow[t]{2}{*}{$0.8 a$} \\
\hline & $\mathrm{No \|}$ & $15(53.6)$ & $13(46.4)$ & $28(24.6)$ & \\
\hline \multirow{3}{*}{ Occupation $2^{\wedge} \mid$} & Until secondary education & $37(56.1)$ & $29(43.9)$ & $66(57.9)$ & \\
\hline & University degree & $15(71.4)$ & $6(28.6)$ & $21(18.4)$ & $0.35 a$ \\
\hline & Does not apply ${ }^{\star \star}$ & $15(53.6)$ & $13(46.4)$ & $28(24.6)$ & \\
\hline Source of & Sexual transmission & $64(57.7)$ & $47(42.3)$ & $111(97.4)$ & \\
\hline \multirow[t]{3}{*}{ infection } & Use of injectable drugs & $0(0.0)$ & $1(100.0)$ & $1(0.9)$ & \multirow[t]{2}{*}{$0.21 a$} \\
\hline & Occupational & $0(0.0)$ & $1(100.0)$ & $1(0.9)$ & \\
\hline & Others & $1(100.0)$ & $0(0.0)$ & $1(0.9)$ & \\
\hline \multicolumn{2}{|c|}{ Time of HIV diagnosis (months) average (SD) } & $54.6(26)$ & $75.3(23.7)$ & & $<0.00 \mathrm{lb}$ \\
\hline \multirow[t]{2}{*}{ Aids case } & Yes & $60(77.9)$ & $17(22.1)$ & $77(67.0)$ & \multirow[t]{2}{*}{$<0.001 a$} \\
\hline & No & $7(18.4)$ & $31(85.6)$ & $38(33.0)$ & \\
\hline Viral load & $<50$ (undetectable) & $55(82.1)$ & $12(17.9)$ & $67(75.3)$ & \\
\hline \multirow[t]{2}{*}{ (copies/ml) } & 50 to 100,000 & $10(52.6)$ & $9(47.4)$ & $19(21.3)$ & $0.04 a$ \\
\hline & 100,001 to 500,000 & $2(66.7)$ & $1(33.3)$ & $3(3.4)$ & \\
\hline Prior history & Yes & $23(57.5)$ & $17(42.5)$ & $40(33.3)$ & \\
\hline of infection & No & $45(56.2)$ & $35(43.8)$ & $80(66.7)$ & $0.9 a$ \\
\hline Total & & & & $120 / 100$ & \\
\hline
\end{tabular}

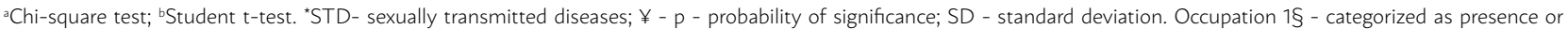
absence of profession; |No - unemployed, students, and homemakers; Occupation 2 - categorized according to the level of formal education; ${ }^{\star \star D}$ Does not apply - unemployed, absence of profession; $\| \mathrm{No}$ - unemployed, students, and homemakers; Occupation 2 - categorized according
students, and homemakers. The frequencies were obtained from the record items that contained valid data.

Socioeconomic factors, such as formal education and marital status, have more influence only in situations of extreme poverty since this can make it more difficult to have access to treatment ${ }^{7}$.

The results in relation to the variable "case of aids" indicate that the likelihood of non-adherence to antiretroviral treatment is reduced by approximately $92 \%$ among individuals who developed the disease.
This indicates that symptomatic individuals adhere more often to treatment.

Probably, the presence of symptoms motivates the search for rigorous clinical monitoring due to the expectation of improvement, which, in turn, causes satisfactory adherence to treatment. The absence of symptoms and feeling of well-being are pointed out as causes for not taking their medicine, since patients 
TABLE 2. RESULTS FROM THE REGRESSION ANALYSIS OF VARIABLES WITH P < O.2 AFTER BIVARIATE ANALYSIS OF THE CHARACTERISTICS OF 120 INDIVIDUALS AGED BETWEEN 13 AND 59 YEARS IN FOLLOW-UP IN THE CENTER OF REFERENCE FOR STD/AIDS VITÓRIA, ES, BRASIL, 2007 TO 2014.

\begin{tabular}{|c|c|c|c|c|c|c|}
\hline \multirow[t]{2}{*}{ Variables } & \multirow{2}{*}{$\begin{array}{l}\text { Coefficient } \\
\text { (Beta) }\end{array}$} & \multirow{2}{*}{$\begin{array}{l}\text { Standard } \\
\text { error (SE) }\end{array}$} & \multirow{2}{*}{$\begin{array}{l}\text { Significance } \\
\text { ( } p \text {-value }) ¥\end{array}$} & \multirow{2}{*}{$\begin{array}{l}\text { Odds ratio } \\
\text { Exp (Beta) }\end{array}$} & \multicolumn{2}{|c|}{ Confidence interval (Cl 95\%) } \\
\hline & & & & & Lower threshold & Upper threshold \\
\hline Age of diagnosis & .452 & .342 & .187 & 1.571 & .803 & 3.074 \\
\hline Age & -.382 & .338 & .259 & .683 & .352 & 1.324 \\
\hline Skin color & .038 & .348 & .913 & 1.039 & .525 & 2.054 \\
\hline Formal education & .136 & .159 & .392 & 1.146 & .839 & 1.565 \\
\hline Time of HIV diagnosis & -.007 & .030 & .807 & .993 & .936 & 1.053 \\
\hline Aids case & -2.527 & .670 & .000 & .080 & .022 & .297 \\
\hline
\end{tabular}

*STD - sexually transmitted diseases; $¥$ - p - probability of significance; $\mathrm{Cl}$ - Confidence Interval.

believed it was not necessary, and only resumed taking it once they started to feel bad again ${ }^{8}$.

In Brasil, a study conducted in 55 health services specialized in the care for patients with HIV/aids showed large variations in the non-adherence rates throughout the country, ranging from $10.7 \%$ to $86.0 \%$. Absenteeism in consultations was a factor that contributed even more to non-adherence and worsened values of CD4 lymphocytes and viral load'.

The issue of the disease symptoms is highly emblematic in literature and incorporates several dimensions, even those attributed to the occurrence of adverse reactions to medications ${ }^{10}$. The patient cannot see the medication as a trial, just using it when they are symptomatic, believing there will be a spontaneous improvement and, at the same time, blame it for the onset of symptoms. This compromises the correct adherence to treatment ${ }^{11}$.

Another important reason for low adherence or even the late start of ART is the stigma. Patients are afraid of being identified as infected by HIV; thus, they avoid care until very late when there are no more choices left, and weakness is inevitable. These aspects reflect a poor understanding of the chronic nature of the disease ${ }^{12}$. In Uganda, a study was conducted that confirms this hypothesis. In it, patients reported difficulties in taking medication when they were close to employers, colleagues, or friends who were not aware of their condition ${ }^{13}$. The irregular follow-up makes it more likely for them to develop symptoms of immunodeficiency. Thus, patients adhere to antiretroviral therapy aiming at a clinical improvement ${ }^{14}$.

This study has limitations related to its cross-sectional design, which prevents a proper assessment of causality, and the fact that its sample was calculated to show large effects, thus limiting its ability to identify valid associations of smaller magnitude. In addition, it was not possible to retrieve information about patient behavioral data due to the scarcity of information in the records analyzed.

On the other hand, the importance of the study lies in the fact that it identifies the presence of symptoms as a potential factor that stimulates adherence. In a scenario of an early start of antiretroviral therapy in infected individuals, the results presented here highlight the importance of developing precise strategies to stimulate adherence, since such individuals are more probable of being asymptomatic ${ }^{15}$.

\section{CONCLUSION}

The AIDS epidemic is currently characterized by the presence of many epidemiological changes in its profile, related to both socioeconomic and clinical aspects. This requires ongoing changes to patient care, which is provided through antiretroviral treatment and various professionals.

The present study fits into the context of the need to establish appropriate strategies to reduce the damages related to HIV infection in individuals. However, there is no intention to exhaust the theme and encompass the full range of issues inherent to a subject as important as the factors that can interfere with adherence to antiretroviral treatment.

\section{Authors contributions}

Kamila Tessarolo Velame - Participated in the conception of the study, its design, data collection, data analysis and drafting of the manuscript. Renata de Souza da Silva - Participated in data collection, data analysis, and critical reading of the first version of the manuscript. Crispim Cerutti Junior - Participated in the conception of the study, its design, data analysis, and drafting of the manuscript. 


\section{Conflict of interest}

There are no conflicts of interest to be declared. Derived from the Master's thesis entitled “Fatores relacionados à adesão ao tratamento antirretroviral em serviço de atendimento especializado", submitted as part of the Graduate Program on Infectious Diseases, at the Federal University of Espírito Santo, Vitória, ES, Brasil.

\section{RESUMO}

O objetivo deste estudo foi verificar os níveis de adesão ao tratamento antirretroviral e os fatores associados a ela. Trata-se de um estudo descritivo de delineamento transversal baseado em levantamento de prontuários. Para tanto, foi utilizado um questionário composto de informações sociodemográficas e clínicas de pacientes com idade entre 13 e 59 anos atendidos em um serviço de atendimento especializado nos anos de 2007 a 2014. Foi realizado o teste do Qui-quadrado para verificar a associação do desfecho com as variáveis categóricas. As variáveis contínuas foram comparadas pelo teste t de "Student" (dois grupos). Treze variáveis foram analisadas no modelo bivariado, sendo selecionadas para o modelo multivariado $(p<0,20)$ : idade de descoberta $(p=0,12)$, idade $(p=0,14)$, cor da pele $(p=0,12)$, escolaridade $(p=0,03)$, tempo de diagnóstico do HIV $(p<0,001)$ e caso de aids $(p<0,001)$. Das seis variáveis selecionadas para o modelo multivariado, permaneceu significante o fato de o paciente ter aids $(p<0,001)$. Concluiu-se que ter aids reduz a probabilidade de não adesão ao tratamento antirretroviral em cerca de $92 \%$. Os resultados indicam que o indivíduo que é sintomático adere melhor à terapia.

PALAVRAS-CHAVE: HIV. Síndrome da imunodeficiência adquirida. Antirretrovirais. Adesão à medicação. Terapêutica. Serviços de saúde.

\section{REFERENCES}

1. Lima TC, Freitas MIP. Health behavior in a population with HIV/Aids. Rev Bras Enferm. 2012;65(1):110-5.

2. Marta CB, Leite JL, Peregrino AAF, Schutz V, Francisco MTR, Magnago C. Costs of adherence to acquired immunodeficiency syndrome treatment: cross-sectional study. Rev Enferm UERJ [Internet]. 2014;22(2):193-9.

3. Freitas MA, Miranda AE, Pascom AR, Oliveira SB, Mesquita F, Ford N. Antiretroviral therapy status among people who died of AIDS - related causes from 2009 to 2013 in Brasil: a population - based study. Trop Med Int Health. 2016;21(11):1452-7.

4. Joint United Nations Program on HIV/AIDS. 90-90-90: uma meta ambiciosa de tratamento para contribuir para o fim da epidemia de Aids [Internet]. 2015. [cited 2016 Nov 19]. Available from: http://unaids.org. br/wp-content/uploads/2015/11/2015_11_20_UNAIDS_TRATAMENTO_ META_PT_v4_GB.pdf.

5. MacCarthy S, Brignol S, Reddy M, Nunn A, Dourado I. Late presentation to HIV/AIDS care in Brasil among men who self-identify as heterosexual. Rev Saude Publica. 2016:50:54.

6. Newcomb ME, Bedoya CA, Blashill AJ, Lerner JA, O'Cleirigh C, Pinkston $M M$, et al. Description and demonstration of cognitive behavioral therapy to enhance antirretroviral therapy adherence and treat depression in HIV-infected adults. Cogn Behav Pract. 2015;22(4):430-8.

7. Colombrini MR, De L'opes MH, Figueiredo RM. Adherence to the antiretroviral therapy for HIV/AIDS. Rev Esc Enferm USP. 2006;40(4):576-81.

8. Teixeira PR, Paiva V, Shima E, eds. Tá difícil de engolir? Experiências de adesão ao tratamento antirretroviral em São Paulo. 2a.0 ed. São Paulo: Copidart; 2000. p.5-26.

9. Santos MA, Guimarães MDC, Helena ETS, Basso CR, Vale FC, Carvalho WMDES, et al. Monitoring self-reported adherence to antiretroviral therapy in public HIV care facilities in Brasil: a national cross-sectional study. Medicine (Baltimore). 2018;97(1S Suppl 1):S38-S45.

10. Silva AL, Waidman MA, Marcon SS. Adhesion and non adhesion to anti-retroviral therapy: the two faces of a same experience. Rev Bras Enferm. 2009;62(2):213-20.

11. Fazito E, Cuchi P, Fat DM, Ghys PD, Pereira MG, Vasconcelos AM, et al. Identifying and quantifying misclassified and under-reported AIDS deaths in Brasil: a retrospective analysis from 1985 to 2009. Sex Transm Infect. 2012;88(Suppl 2):i86-94.

12. Ortblad KF, Lozano R, Murray C). The burden of HIV: insights from the Global Burden of Disease Study 2010. AIDS. 2013;27(13):2003-17.

13. Hardon AP, Akurut D, Comoro C, Ekezie C, Irunde HF, Gerrits T, et al. Hunger, waiting time and transport costs: time to confront challenges to ART adherence in Africa. AIDS Care. 2007;19(5):658-65.

14. Prado TN, Rajan JV, Miranda AE, Dias ED, Cosme LB, Possuelo LG, et al. Clinical and epidemiological characteristics associated with unfavorable tuberculosis treatment outcomes in TB-HIV co-infected patients in $\mathrm{Bra-}$ sil: a hierarchical polytomous analysis. Braz J Infect Dis. 2017;21(2):162-70.

15. Luz PM, Veloso VG, Grinsztejn B. The HIV epidemic in Latin America: accomplishments and challenges on treatment and prevention. Curr Opin HIV AIDS. 2019;14(5):366-73. 